THE 13th INTERNATIONAL CONFERENCE OF

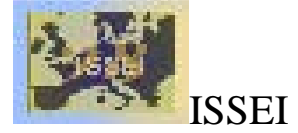

International Society for the Study of European Ideas in cooperation with the University of Cyprus

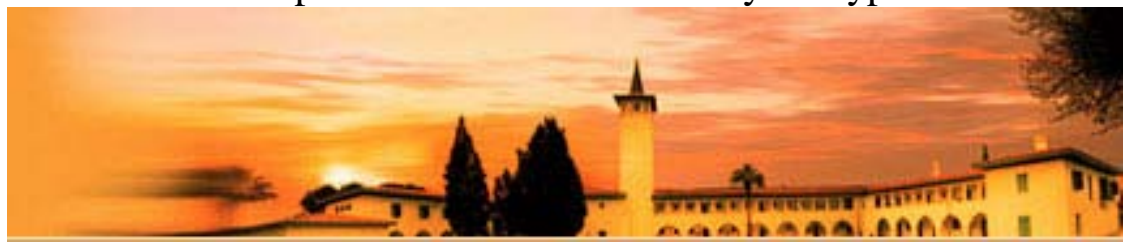

\title{
Writing trauma:
}

Narrative Catharsis in Homer, Shakespeare and Joyce

Richard Kearney

'Myself unto myself do give

This name Katharsis-Purgative'

(James Joyce, 'The Holy Office')

\section{I}

James Joyce, in a letter to his brother Stanislaus on November 13, 1906, announces that he has just started a new 'short story'. It is called 'Ulysses'. He came up with the idea, he explains, because of a memory triggered by a recent mugging in a street in Rome. He had just been fired from his job at the Bank and drunk all his severance pay (which should have paid the rent and help provide for his one year 
old son, Giorgio). On his way home Joyce was robbed and left lying in the gutter, destitute, despondent and bleeding. And it was at that very moment that he suddenly remembered something: being assaulted several years previously (June $22,1904)$ in Dublin and rescued from the gutter by a man called Hunter, 'a cuckolded Jew' who dusted him down and took him home for a cup of cocoa. 'In true Samaritan fashion', as Joyce put it. This repetition of woundings triggered a lost memory where an immigrant Jew came to the rescue of a wounded Dubliner and planted a seed of caritas in his imagination.

Several weeks after the Rome mugging, Joyce and Nora were given tickets to an opera whose librettist was called Blum. This second moment of happenstance, after his humiliating fall in a Roman side street, furnished the name of his paternal protagonist, Leopold Bloom.

Thus was born the longest short story ever told. Ulysses. The tale of a father and a son traversing wounds on the way to healing.

My subject is the writing cure. My questions are the following. How might literature help us 'work through' trauma? How far can narrative catharsis go and what are its limits? And finally: how might narrative healing differ in the case of little trauma (the existential wounds of birth, loss and death) and big trauma (war, torture, catastrophe)? My chosen example is Joyce's Ulysses - itself a story which rewrites two other stories, Shakespeare's Hamlet and Homer's Odyssey. All three are stories of fathers and sons. Stories of transgenerational trauma, which I will 
suggest, are transmitted and somehow transfigured in the writing of the stories themselves.

In the opening of Joyce's Ulysses we are told by Haines that it's all about 'the father and the son idea. The son striving to be atoned with the father'. It doesn't take long for us to realize that the son is Stephen-Telemachus and the father Bloom-Ulysses. Their paths cross in the middle of the book as Stephen exits and Bloom enters the National Library in Dublin. It is a pivotal scene in which Stephen expounds his central theory of the father/son idea in Hamlet. His thesis is that Shakespeare wrote Hamlet the year his son, Hamnet, died and his own father, John Shakespeare, was dying. The play is about the transmission of mortal trauma between fathers and sons. In short, according to Stephen, Shakespeare wrote 'the book of himself' in order to avoid the madness of melancholy, in order to properly mourn his father and his son in a way that he was unable to do in life. The play itself thus serves as a symbolic 'working through' of an otherwise irresoluble crisis in which a father (King Hamlet) commands his son (Prince Hamlet) to do something impossible: that is, to remember what cannot be remembered! To tell something that cannot be told. A double injunction. An unbearable burden. An impossible story. The double bind of trauma. 'To speak is impossible, not to speak is impossible' (1). 
'Remember me, remember me...' , says the ghostly father to his son, while at the same time adding:

'But that I am forbid

To tell the secrets of my prison house

I could a tale unfold whose lightest word

Would harrow up thy soul...(Hamlet, act 1, sc 5)

The ghost's unspeakable secrets - for which he is condemned to the latency of purgatory, those 'sulphurous and tormenting flames' - these very things are precisely what remain secret. The secret 'crimes committed in his days of nature' (youth) are, King Hamlet tells us, forbidden tales. In short, the things to be remembered cannot be told in the first place!

We are concerned here, I suggest, with traumas. Unspeakable things which we do not possess but which 'possess us' - like specters. For traumas, as Cathy Caruth writes, describe 'overwhelming experiences of sudden, or catastrophic events, in which the response to the event occurs in the often delayed, and uncontrolled repetitive occurrence of hallucinations and other intrusive phenomena' (2). I think Hamlet perfectly qualifies. 
Now, if this reading of Ulysses sounds psychoanalytic it is because it is. Joyce himself admitted to being deeply interested in Jung and Freud when he was 'jung and easily freudened' (Finnegans Wake). And the story is well known of him bringing his daughter, Lucia, to visit Jung in Zurich only to be told by Jung that he would be as incurably psychotic as his daughter if he had not penned Ulysses. Writing his book of transgenerational trauma - of Ulysses and Telemachus, of King and Prince Hamlet, of Stephen and Bloom - was, it seemed, the 'writing cure' for Joyce's own trauma. The book of himself. And Joyce concedes the creative liaison between literature and life when he confesses: 'It is a brave man who would invent something that never happened'. What happens in Ulysses happened to Joyce. He was the manic magpie who, by his own admission, gleaned every word of his story from the stories of history, personal or collective. His fiction is haunted by what he called the 'nightmares of history', the mute 'mothers of memory' that cry out to be heard, spoken, written. Phantasmal hauntings torment the young Stephen with 'agenbite of inwit'. They revisit him obsessively, guiltily, ineluctably. Both Hamlet and Ulysses relate such ghostings of narrative memory (3).

As for Freud, no such meeting took place; but I sometimes imagine Joyce reading Freud's seminal theory of trauma in Beyond the Pleasure Principle published in 1920 as Joyce was completing Ulysses (1922) - and wondering when he came to the fort/da scene if it did not confirm his own theory of catharsis in the Portrait? Recall how Freud witnessed his grandson Ernst's first spoken words gone/back again - while playing with a wooden cotton-reel which he made vanish under his curtained cot and then reappear again in imitation of his mother's coming 
and going from the house, a cause of unbearable separation anxiety for the young child. In Freud's famous account of little Ernst's two syllable tale - fort/da - invented to compensate for the little 'trauma' of his parents' absence ( mother away, father at war) might not Joyce have recognized echoes of his own fictional ploy to compensate for intolerable loss? In other words, might not both Freud and Joyce have witnessed the magical power of words to 'work through' wounds, albeit at very different levels? Working through as writing through? And more precisely, when Freud wrote of his grandson's loss of his mother was he not also writing about his own loss of his daughter: the same person - Sophie Freud. For Sophie was, significantly, Freud's favorite daughter who died tragically in January, 1920, several months before Freud, devastated by the loss, wrote the fort/da scene. (This scene, incidentally, is inserted in the book's narrative, quite abruptly, after Freud's initial outline of a series of examples of WW1 trauma. And this interpolation of a 'little trauma' - separation from a loved one - into Freud's seminal account of 'Big Trama' - unspeakable violence at war - opens up, I believe, the whole conversation about relations between ordinary and extraordinary trauma).

My suggestion here is that the mirror play of Sophie Freud's 'disappearance', enacted between her father (Freud) and her son (Ernst), is a micro-drama of transgenerational trauma (with a small t). It signals a crossing of identifications where Freud is at once Sophie's father and son, 'writing the book of himself', as Joyce puts it, so as to mourn a departed loved one (a lost object). My corollary suggestion is that Joyce may have found writerly resonances in Freud's therapeutic narrative of fort/da. The longest short story ever told echoing the shortest!(4). 
This hypothesis is fantasy - but Joyce was a voracious reader and he does have his Finnegans Wake narrator boast: 'I can psoakoonaloose myself any time I want'! (FW 11, 31-4, Penguin edition, p 522).

III

So, to return to Ulysses. When Stephen tells us that Hamlet is the story of Shakespeare's father-son relationship, he is echoing his relationship with his own fathers (Mr Dedalus and Bloom). And this story within a story is - please bear with me! - itself a parody of Homer's original story of Ulysses and Telemachus. In other words: we are dealing here with stories within stories within stories. Fathers and sons, repeating, reliving and (perhaps to some significant extent) relieving trauma. Narrative as catharsis. But not narrative catharsis understood as closure or completion. Rather narrative as impossible story: storytelling which forever fails to cure trauma but never fails to try to heal it. And in this very effort itself there is pleasure: the pleasurable purgation of pity and fear (5).

Now, let's go back to the beginning. Homer's Ulysses. It is a standard motif of Greek myth that sons act like father's before them. Like father like son, and so on ad infinitum, until someone says 'stop!' That someone is the true storyteller who transposes the regressive repetition of trauma in life into a cathartic repetition in narrative. Think of the great cyclical myths. Zeus castrating Saturn castrating Ouranos. Orestes reiterating the curse of the house of Atreus. Or perhaps, most 
famously, Oedipus repeating the deeds of his father Laios. Recall: Laios raped the son of his host, Pelops, thereby committing the equivalent of incest and the betrayal of hospitality. His double transgression replicates the curse (ate) of his own father, Labdacos, and is repeated by Oedipus in the next generation. The continuing narrative lineage comes under the heading of the 'House of Labdacos' and involves a recurring acting out of unspoken traumata (Greek for 'wounds').

Lévi-Strauss has remarked how the three names of patrilinear descent in the story - Labdacos (lame), Laios (left-sided), Oedipus (swollen footed) - all refer to wounds which cause difficulties in walking. This fact, he suggests, which is symptomatic of a transfer of trauma over three generations (and four if one includes Antigone and wishes to open the discussion to fathers and daughters and, by extension, to contemporary feminist readings) (5a). The only solution to this curse of cyclical repetition is the conversion of the untold wound into some form of telling - in this case, the symbolic emplotment of Oedipus's tragic narrative. Only this, according to Lévi-Strauss after Aristotle, can bring some sort of catharsis which suspends - through the purging of pity and fear - the compulsive acting out of mute trauma. The basic thesis, in sum, is that myths are machines for the purging of wounds: strategies for resolving at a symbolic level what remains irresolvable at the level of lived empirical experience.

Human existence is cursed by a tragic, because impossible, desire to escape the trauma of our autochthonous origins. Namely, the desire to buck our finitude. To deny death. In the Oedipus cycle, this tragic curse is epitomized, as noted, by the patrilineal names for wounds that bind us to the earth. And the poetic role of 
muthos-mimesis that comprises tragic drama (as Aristotle reminds us in the Poetics) is to narrate our heroic desires to transcend our terrestrial nature: Cadmos kills the dragon, Oedipus defeats the sphinx. But our desires are ultimately impossible: we are scarred by contrary and irreconcilable fidelities: to earth and sky, to immanence and transcendence, finitude and infinity, matter and spirit, nature and culture. For Lévi-Strauss, great mythic narratives - beginning with the synchronic myths of $l a$ pensée sauvage - are attempts to procure cathartic relief by balancing these binary opposites in symbolic constellations or 'mythemes'. In a word: what is impossible in reality becomes possible in fiction (6).

\section{IV}

So how might this reading relate to the father-son story of Ulysses and Telemachus? Let me say a word about Homer's version and then proceed to Joyce's. Ulysses is condemned to act out the wound of his own failure, his own existential finitude, again and again. He has absented himself from the wounds of his birth and upbringing, his autochthonous origins in Ithaca, sailing off to heroic glory. But his attempts to become an immortal warrior are constantly countered by reminders of mortality (the brutal carnage of Troy and subsequent calamities). And the breaking of the lure of Calypso is also central to his disillusionment. Originally leaving Ithaca as an aspirant hero, Ulysses returns as a beggar: a lowly outcast only recognized by the smell of his flesh (by his dog, Argos) and the scar on his thigh (by his nurse, Euryclea). It is significant that Euryclea only touches her master's scar after a detailed narrative about how Ulysses received the original wound in a childhood 
hunting incident with his grandfather, Autolycus (bk 19, v 393-469). Yet another example of transgenerational trauma. (Note that this narrative 'working through' leading up to the final, healing touch, takes all of seventy seven lines) (7).

Telemachus, expecting a triumphant victor to return, does not at first recognize Ulysses; he is so fixated on his Great Expectations of the father that he does not see the 'scar' on his body. He is blinded by illusory imagos. Delusions abound. When he finally acknowledges that the mortified stranger before him is in fact his real father, they sit down together and eat. Sharing simple food of the earth, squatting in a swineherd's den, is how they finally come together as host and guest. Hospitality as antidote to the hostile curse of fate (ate).

The word Homer uses for 'scar' here is oulen (Od, 19.391). This is a term often associated in Greek literature with 'trauma', as in Plato's Gorgias, 524c, "oulas en to somati...hypo traumaton' where oulen means both 'trace' and 'scar'. While the wound is timeless, the scar appears in time: it is a carnal trace which can change and alter over time though it never disappears. Scars are written on the body; they are forms of proto-writing. And narrative catharsis is a process of working through such carnal traces. Put simply: while the wounds remain timeless and unrepresentable, scars are the marks left on the flesh to be seen, touched, told and read. Scars are engraved wounds that may, or may not, be healed (8). I shall return to this distinction below. 
So how, in the light of all this, does Homer's epic compare with Joyce's parody? Quiet apart from the fact that we have leaped three thousand years - from a 'cold' synchronic literature to a 'hot' diachronic one - the 'father-son idea' repeats itself. But the repetition is forward not backward. That is what writing can do: give a future to the past. Joyce's narrative invites a release from the haunting cycle of trauma. The story of Stephen and Bloom recounts their respective efforts to escape the loss of absent parents (Stephen's mother and father) and a departed son ( Bloom's prematurely departed son, Rudy). They both seek a new bond of spiritual paternity-filiality; but they cannot find it for as long as they remain captive to their illusions of what this should be - Stephen's fantasy of perfect fusion and Bloom's obsession with his lost son. Only when they accept their condition of wounded finite beings - Stephen breaking with the literary elite of Dublin, Bloom returning home to Molly (with 'less envy than equanimity, less jealousy than abnegation'). Only then can arise a love beyond illusion. Surrogate father and surrogate son exchange stories of failure and mourn lost illusions. Such love beyond loss is only a hint of course, a glint in Molly's matinal eye. But enough of a narrative catharsis, nonetheless, to give the reader hope in another day - in beginning again. 'Childman weary, manchild in the womb'(9). 
So, to return one last time to Hamlet, we might ask this: why does Stephen Dedalus choose this particular story to work out his theory of the father-son idea? Let's take a closer look.

The ghost of King Hamlet asks his son to remember something that cannot be remembered. So, as already noted, the play begins with a tale that cannot be told, a testimony that cannot be transmitted - thereby breaking with the age-old sacred tradition of death-bed blessings passed from fathers to sons. (This breakage is an example of what Dori Laub calls the 'collapse of witnessing')(10). Hamlet, we saw, knows his father is condemned to flames for a secret sin committed in his youth. But his father is forbidden by this very same sin to say what this is, that is, from telling his story. So Hamlet inherits a double injunction: remember, don't remember. (A confusion confounded by a supplementary injunction: intervene to stop your mother's incest, but don't do anything: 'let not thy soul contrive against thy mother aught'! No wonder the Dane is confused!) Thus here, as in many ancient narratives of trauma, blind acts of murder and incest are encrypted rather than confessed. Whence the inheritance of the wound as a mark in one's flesh - what Hamlet famously calls 'the mole of nature' which one inherits with one's birth. Hamlet spends the entire play trying to 'catch the conscience of the King', deploying the 'antique disposition' of mask and subterfuge, pun and quip, play and wit, so that he might 'by indirection find direction out'. But working through takes time. Patience. Five full acts! Truth only ultimately reveals itself when Hamlet succeeds in abandoning his illusions about a perfect father - 'look here upon this picture and on 
this...' (Act 3, sc 2) - and accepts that he, no less than his father before him, is a failed, forked, mortal, finite thing. Henceforth, 'the readiness is all'.

This surrender of idealised imagos reaches its climax in the famous graveyard scene when Hamlet comes to realise that the father who loved him as a child and bore him daily on his shoulders was not, as he had imagined, his natural father, King Hamlet, but the long buried court jester, 'poor Yorick'. Only then is Hamlet the son ready to act according to something beyond himself - ' a divinity that shapes (his) ends' - acknowledging his own mortal condition. Now the 'readiness is all'. And here, as in King Lear, wisdom comes from the lowliest of creatures. Hamlet the son dies, the play hints, poisoned by the same sword that Hamlet the father used to poison King Fortinbras on the day Hamlet was born. And, to follow this hint of the grave scene, it was this secret poisoning which led to the cycle of further killings of Kings by Kings (Fortinbras, Hamlet, Claudius) and sons by sons (Hamlet, Laertes and - almost - Fortinbras). Inhumations and exhumations. Cryptings and decyrptings Secrets of the grave whisper through the mouths of fools.

This fatal circle of repetition only comes to an end when Hamlet himself becomes the sacrificial symptom of cyclical acting out and exposes the wound in his own body where the sword entered. Note that the fatal wounds of King Hamlet's body were never seen or touched by his son as 'scars', for the poisoned King was 'to his grave untimely sent', his prematurely decomposing body having to be interred without ceremony: Hamlet never saw the corpse of his father - just as Shakespeare himself, as Stephen reminds us, never saw the corpse of his son, Hamnet. The wounds were never witnessed as scars. Once again, we find a 'collapse of 
witnessing' which makes for traumatic 'delay'. Traumas are revisited as ghosts, coming back again and again, after the event, revenants après coup. Freud's Nachträglichkeit.

(This phenomenon of delay is extremely relevant, I think, for an understanding our own contemporary culture's fear around dying and death. In former times, mourners were encouraged to have direct and sustained funerary witness of dead bodies before burial (think of the Irish wake for example). And this culture of deathdenial is manifest today in all kinds of symptomatic avoidance behavior faced with the wounds of disabled and otherwise scarred persons. To take just one example: might not a mass social media phenomenon like Facebook - where we 'prepare a face to meet the faces that we meet' in a virtual climate of mandatory cheer - might this not also prove to be, deep down, a book of ghosts?)

Let me sum up. Because the son did not witness the father going down into his grave this absence was engraved in his flesh. The loss, the lack, the gap of the empty grave, the missingness, all this was encrypted as a suppressed 'right of memory' waiting five full acts of 'procrastination' to be retrieved. This is, perhaps, the reason T.S. Eliot described Hamlet as an 'artistic failure' if also the most written about drama in western culture. And it is also the reason why André Green describes Hamlet as the greatest literary performance of unconscious trauma and recovery, to which psychoanalysts have been endlessly drawn like kittens to a ball of wool! (11).

In short: Fathers and sons - sons and fathers. Eventually it is Hamlet's own sacrificial surrender which enables the play's other fatherless son, Prince 
Fortinbras, to live on: to survive the fatal curse which ghosted the whole revenge cycle for generations. Hamlet's dying words to Horatio say it all, 'absent thee from felicity awhile/to tell my story'. The story that could not be told is finally told though it took five acts. And the closing words of the Fifth Act are delivered by Fortinbras himself, finally set free - by Hamlet's sacrifice - to recover the crypted memory of his father: 'I have certain rights of memory to this kingdom', concludes Fortinbras, 'which now to claim advantage doth invite me'. Memory and story cross in morning. And if there is catharsis, for us the audience, it is indeed a purging of pity and fear.

\section{VII}

Much more could be said here about narrative catharsis.

There is Aristotle's theory of cathartic affect in the Poetics and Joyce's rewriting of it in A Portrait of the Artist. There is the difference between catharsis as it effects the author and the audience: where Aristotle focuses on the purgation of the spectators' emotions, Joyce also applies it to narrators, real or implied. His own poetic persona included:

Myself unto myself do give

This name Katharsis-Purgative...

Bringing to Tavern and to Brothel

The mind of witty Aristotle.

('Holy Office') 
Then there is the question of the respective therapeutic roles of imagination, cognition and emotion (Paul Ricoeur, for example, has much to say on this in his rereading of Aristotelian catharsis in Time and Narrative) (12). And there is, crucially, the difference between catharsis in lower case trauma - the 'originary traumas' of birth, loss and death) - and in upper case trauma - torture, rape, abuse, catastrophe and genocide (13). These latter examples of Big Trauma often involve such appalling terror (Schreck) that several experts claim - among them Judith Herman, Berel Lang and Claude Lanzmann - that no catharsis is possible at all. This last point raises the critical question of the ultimate limits of catharsis: what traumas may, or may not, be subject to narrative healing (14).

I would like to repeat, in closing, that we need to think about the genuinely cathartic role of trauma stories as requiring open narratives that never end, rather than closed narratives that presume to wish away wounds rather than working through scars. Trauma narratives are by their very nature truncated, gapped, fractured, inconclusive. They may be great stories but they can never offer terminal solutions. There are no total cures. Writings can only work through traumas as traces, revisit them as hauntings; they can never fully retrieve such experiences or tell the full story. In the transposition from inexpressible wound to written scar there is something lost in translation. Invariably. Why? Because the 'wound' is precisely that which could never be properly registered or recorded in the first place. It was because it was 'too much' that trauma repeats itself as lack. Trauma narratives are scabs over the cavities left by inexperienced experience. 
Recall, in conclusion, our three stories.

The trauma inherited by Hamlet - namely, his father's murder by Claudius on top of his father's sin committed on Hamlet's birthday- is something hinted at in the play; it is never openly stated. Moreover, the fact that his father's death and burial are 'missed' by Hamlet - who was absent in Wittenberg - is a further token of 'inexperienced experience'; and this is linked in its own murky way with Hamlet's mother's incest with Claudius. Secrets everywhere. Plays within plays. Cypherings and decypherings. (Which is why André Greene, Nicolas Abraham and other psychoanalysts have hunted obsessively to untangle the mystery - without success)(15). Shakespeare's drama engraves traces of buried trauma which Hamlet resolves to exhume - as in the grave diggers' scene - but never finally exposes. Many bodies are rotten and rotting in the state of Denmark (from its eponymous King to the disappeared Polonius). But they are all hidden away. Behind walls and wainscotings, lies and disguise, screens and 'seems'. All we have are odors, ashes, allusions - oblique ciphers less deciphered than played with (like cotton-reels or gallows wit) and played out (in imitated suffering and action).

In this sense the play's very success is its failure. Hamlet's manic-melancholic words swarm like bees over the black hole of an empty hive. But they can never fill in the gaping wound; only, at best, conjure and confront the invisible ghosts within. The narrative catharsis comes ultimately not from the cognition of discovery (we never know exactly what happened) but a curiously liberating recognition of recovery. Failing to gain full knowledge of his father's unspoken crime (laconically mentioned in Act 1), Hamlet nonetheless comes to acknowledge the limits of his 
own finite, humble existence - his crucial lesson in the grave scene. Indeed, the fact that King Hamlet's hidden story (the real reason he is condemned to purgatory) remains buried throughout the play, only returning as spectral intimation, itself performs Prince Hamlet's inability to discover his own story and, by extension, our own inability, as audience, to discover the unfathomable story of the play. Hamlet is a tragedy of trauma: it recounts the impossibility of saying the unsayable.

Similar issues of 'unsayablity' surround the unspoken traumas of Stephen and Odysseus. There are signs here too but they too are equally crypted: Stephen's overdetermined guilt, Odysseus' occluded scar. And we, as readers, may in turn hypothesize about the nature of the various authors' own engraved wounds. For instance: What Homeric trauma, personal or collective, lies behind the long forgotten story of Odysseus's infantile wound? How deep was Shakespeare's shame at missing his own son's funeral, currying favor with a barbarous Queen, abandoning his father's forbidden Catholicism? And, to give Joyce the last word: what traumas, little or big, may have been reactivated by his incidental mugging in a Roman night street? Guilt at abandoning his mother and family? The painful break with his city and culture? Or perhaps, father back still, the untold historical rupture inherited from the Great Irish Famine with its extinctions, evictions and exiles?

This last transgenerational wound is rarely acknowledged by Joyceans (itself arguably a symptom of elusiveness). But for all its neglect it is, I suspect, a key aspect of Joyce's native unconscious. Joyce himself was born in 1882 less than thirty years after The Great Hunger ended, a catastrophe that split Ireland into pre and post famine history witnessing a million dead and another million banished (almost 
a third of the population between 1847-1852). Joyce's father and grandfather lived through this unspeakable horror though like most witnesses who survived at home or abroad, the pain of an Drochshaol (or 'bad times' as they were elliptically known in Irish) went largely unwritten at the time. So if Stephen vows at the end of $A$ Portrait to 'forge in the smithy of his soul the uncreated conscience of his race', is it not logical that this massive gash in the national psyche would return in his next novel, Ulysses, as an irrrepressible haunting? A stammering tale demanding to be heard?

This is, I submit, what happens. The references are oblique but they are pervasive, as Luke Gibbons and other critics have recently shown: from Stephen's dead mother's phantasmal returns to Bloom's frequent allusions to hunger, soup kitchens and potatoes - he even carries one in his pocket as talisman! (16) 'You don't know whose thoughts you're chewing on', muses Bloom, 'Famished ghosts. Ah I'm hungry'. Or as the Daughters of Erin (also called the 'daughters of memory') sing in the 'Circe' episode: 'Potato, Preservative against Plague and Pestilence, Pray for us!' The allusions are multiple if characteristically muted. Much hermeneutic digging is required. Here as in Hamlet's graveyard or Odysseus' childhood. (Yorick and Euroclyea as child reminders). Throughout, wounded authors call for readers, traces for interpretations, hints for guesses, cyphers for thoughts.

To sum up: Joyce's narrative of his native psyche shows that past wounds are never completely past, no matter how much one prays. The psychic palimpsest of personal and historical abandonment finds expression in the ineradicable wounds of what Stephen calls 'banishment from the heart, banishment from the home' (17). 
Joyce identified similar experiences of 'sundering' in both Shakespeare and Homer whose traumatized heroes also carry indelible scars of exile and injury. Like his literary predecessors before him, Joyce grafted stories onto histories - forgotten, repressed, occulted or stolen. His narratives were secreted from those 'nightmares of history' which, by Joyce's own admission, made his writing 'the last word in stollentelling'. Ulysses is, I wager, a tireless literary effort to awaken, cathartically, from such historic nightmares by restoring forfeited stories and bringing ghosts back to life. It is, in short, a work of mourning and recovery. A writing which translates wounds into scars, flesh into fiction. A working through of trauma. 


\section{NOTES}

1) Schreiber Weitz cited by Cathy Caruth, Trauma: Explorations in Memory, ed, Cathy Caruth, The Johns Hopkins University Press, Baltimore, 1995, p. 154. On this double injunction to tell and not tell trauma, see also Richard Kearney 'Hamlet's Ghosts: From Shakespeare to Joyce' in Strangers, Gods and Monsters: Interpreting Otherness, Routledge, London and New York, 2003, pp 141-162. On Joyce's 1906 letter to his brother, Stanislaus, about the Bloom/Hunter connection, see Richard Ellmann 'Ulysses: A Short Story’, Appendix to the 1968 Penguin edition of his James Joyce: A Biography, pp $705 \mathrm{f}$ and Giorgio Melchiori, 'The Genesis of Ulysses' in Joyce in Rome, ed. G. Melchiori, Bulzoni Editore, Rome, 1984, p 37f. On the Ulysses/Hamlet connection see Declan Kiberd Ulysses: Annotated Student's Edition, Penguin, London and New York, 1992, p 1013 and Ulysses and US, Faber, London, 2009. Kiberd argues that just as Joyce sought to become his own father by writing Ulysses, so too Shakespeare sought to become his own father (as Ghost) of his literary son (Prince Hamlet). He also notes the revealing fact 
that Shakespeare's son Hamnet was eleven when he died and Bloom recalls in his final bedtime reverie that it was almost eleven years since his son, Rudy, had died. On Stephen Dedalus' theory of Hamlet see also René Girard, 'Croyez-vous vous-même à votre théorie?' in Shakespeare: les feux de l'envie, Grasset, Paris, 1990, pp 313-330 and Harold Bloom, 'Hamlet' in Shakespeare: The Invention of the Human, Riverhead Books, New York, 1998, p 390: 'For him (Joyce/Stephen), Hamlet the Dane and Hamnet Shakespeare are twins, and the ghostly Shakespeare is therefore the father of his most notorious character'. For other pieces of information on the father/son motif in Ulysses I am also grateful to my Joycean colleagues, Joseph Nugent, Joseph O’Leary, Luke Gibbons and Susan Brown.

2) Cathy Caruth, 'Unclaimed Experience: Trauma and the Possibility of History', Yale French Studies, 79 in Literature and the Ethical Question, ed Claire Nouvet, Yale UP, New Haven, 1991, p 181. Caruth adds: 'The experience of the soldier faced with sudden and massive death around him, for example, who suffers this sight in a numbed state, only to relive it later on in repeated nightmares, is a central and recurring image of trauma in our century' (ibid). For other current definitions of trauma - especially relating to major horrors of war, rape, torture, genocide and natural catastrophe - see Judith Herman, Trauma and Recovery, Harvard University Press, Cambridge, 2002; Charles Figley (ed), Trauma and Its Wake, vols 1 and 2, Brunner-Mazel, New York, 1985-1986.p 181; Shelley Rambo, Spirit and Trauma, WJK, Louisville, Kentucky, 2010, especially ch 1, 'Witnessing Trauma', pp 1-15; and Dori 
Laub, 'Re-establishing the Internal 'Thou' in Testimony of Trauma' (paper delivered to the Psychoanalytic Studies Program at Boston College, December, 2011 and published in a special issue of the journal, Psychoanalysis, Culture and Society, 2012 edited by Judith Alpert) and Dor Laub with Shoshana Felman, Testimony, Routledge, New York and London, 1992. See also the texts cited in Notes 13 to 15 below.

3) See Paul Ricoeur on various kinds of memory - 'blocked', 'dangerous' and 'therapeutic' - in History, Memory and Forgetting, University of Chicago Press, 2006 and, in a shorter essay version, in 'Memory and Forgetting' in Questions of Ethics: Contemporary Debates in Philosophy, ed Richard Kearney and Mark Dooley, Routledge, London and New York, 1999, pp 5-11. See also Ricoeur's reflection on narrative testimonies of the holocaust, "The Memory of Suffering' in Figuring the Sacred: Religion, Narrative and Imagination, Fortress Press, Minneapolis, 1995, pp 290, and our own discussion of the spectral dimensions of trauma and repressed memory in literary, historical and testimonial narratives - including Hamlet - in Richard Kearney, 'Narrative and the Ethics of Remembrance' in Questioning Ethics: Contemporary Debates in Philosophy, ed Richard Kearney and Mark Dooley, pp 18-32. One might also mention here Jacques Derrida's reading of Hamlet as 'hauntology' in Specters of Marx: The State of the Debt, the Work of Mourning and the New International, Routledge, New York and London, 1994 as well as his commentary on Nicolas Abraham and Maria Torok's work on 'cyrptonomy' in The Secret Kernel (see note 15 below). 
4) Sigmund Freud, Beyond the Pleasure Principle translated by Gregory Richter with a critical Introduction by Todd Dufresne, Broadview editions, Toronto and New York, 1984 and 2011, p 55-65. The incident of little Ernst playing with the spool of string occurred in 1915 when Freud visited the Hamburg home of his daughter Sophie, who later died in January 1920 as Freud was still composing his text. See also the commentaries by Derrida in The Postcard: From Socrates to Freud and Beyond, trans Alan Bass, University of Chicago Press, Chicago, 1996 and Eric Santner, 'History beyond the Pleasure Principle' in Probing the Limits of Representation, ed Saul Friedlander, Harvard University Press, Cambridge, Mass, 1992, pp 143-155. Might there also be a basic isomorphic rapport between 1) the primordial therapeutic play fort/da and 2) the cathartic play of pity (identification with immediate suffering here $/ d a$ ) and fear (distance of the one who detaches, mediates and lets go there/ fort) as expounded by Stephen Dedalus in A Portrait of the Artist as a Young Man? If this is so, we might be tempted to ask what the equivalent of Ernst's spool play is in Joyce's own writing? Is Stephen, to put it fancifully, his fort and Bloom his da? And what role has Molly in the drama of pity and fear? Does she turn the tragic purgation into comic serenity? The split dyad of father/son into a dialectical triad? We might draw useful suggestions here from feminist reinterpretations of the fort/da game by such thinkers as Luce Irigaray, Sexes and Genealogies, trans G. Gill, Columbia University Press, New York, 1993, and more recently, Anne-Claire Mulder, 
Divine Flesh, Embodied Word, University of Amsterdam Press, 2006, chapter 1 , pp $41 \mathrm{f}$.

5) See Paul Ricoeur's reading of Aristotle's notion of cathartic pleasure in Time and Narrative, University of Chicago Press, Chicago, 2004, Vol 1, chapter 2. But it is not only dramatic or epic stories that serve as narrative therapies for the purgative relief and release of traumatic blockage; there is also, as Joyce learned from Aristotle, a third category, the lyric: namely poetic micronarratives (or sometimes post-narratives and non-narratives) that may supplement or even supersede the standard narrative forms. A telling example of this in Joyce's case, I believe, is his late poem, 'Ecce Puer', written on the birth of his grandson, Stephen Joyce, in 1932, though not published until 1936 in Collected Poems. Here, in my view, is another attempt, however minimal and modest, to address the enigma of transgenerational trauma - in this case that between grandfather/father/son. The last line of the poem, ' 0 father forsaken, forgive your son', sees Joyce skipping a generation to seek forgiveness by identifying with his own son, Giorgio, via his own grandson, Stephen. In so doing, Joyce reprises both the closing lines of the 'Ithica' episode of Ulysses ('Childman weary, manchild in the womb') and also the final lines of A Portrait where Stephen-Icarus addresses his mythical father, Dedalus: 'Old father, old artificer, stand by me now and ever in good stead'. Thus ' $\mathrm{O}$ father forsaken, forgive your son' mirrors ' $\mathrm{O}$ son forsaken forgive your father'. To repeat: in 'Ecce Puer', Joyce writes about the birth of his grandson and not his own son as some commentators assumed. It is as if the 
birth of his grandson - by a sort of intergenerational leap - enabled Joyce to revisit the birth of his own son, Giorgio, who he was not in a position to properly welcome and celebrate at the time of his actual birth (in poverty in Trieste in July, 1905, just over a year before the 'negative epiphany' of Joyce's mugging in Rome in Nov, 1906. At the time of embarking on Ulysses right after that mugging, Joyce surely felt himself to be a defaulting father with regard to Giorgio and a defaulting son regarding his own father whom he had largely disowned and abandoned in Dublin). So in 'Ecce Puer', written in 1932 after his grandson Stephen's birth and 27 years after his son, Giorgio's, we witness a transgenerational transfer of father and son through grandfather and grandson. The title 'Ecce Puer' refers of course to Pontius Pilot's words, 'Ecce Homo', as he presented the wounded Christ to the crowd before his death, a phrase repeated by Nietzsche in his work Ecce Homo which Joyce most probably read. The full poem reads:

of the dark past

A child is born;

With joy and grief

My heart is torn.

Calm in his cradle

The living lies.

May love and mercy 
Unclose his eyes!

Young life is breathed

On the glass;

The world that was not

Comes to pass.

A child is sleeping:

An old man gone.

0 , father forsaken,

Forgive your son!

It is significant I think that in his poem, 'The Holy Office', written in the 'dark past' of 1904, two months before he left Dublin for permanent exile, Joyce presents himself under the pseudonym 'Katharsis-Purgative' (verse cited in our conclusion). His self-nominated role as author would thus appear to be not only to 'forge' but also to 'purge' the 'uncreated conscience of his race'. And for conscience here we may read not only moral-social-cultural consciousness but also the psychic unconscious. Joyce, an erstwhile medical student in the National University in Dublin, saw himself (ironically or seriously or 'jocoseriously') as a form of literary doctor for his own people, who he diagnosed in Dubliners as suffering from a deep national 'paralysis' and resolved to 'psoakoonaloose' to the best of his poetic abilities. His 
medication was a mixed dose of 'silence, exile and cunning' - with more than a spoonful of 'writing'. In this way, he vowed to explore the 'nighttime consciousness' of his culture, characters and himself as author-narrator.

5a) The feminist perspective is relevant here. The frequent omission of mothers and daughters from the 'phallogocentric' tradition of male-authored western literature, where fathers and sons reigned, is not to be taken as paradigmatic. It is a symptom of cultural history. That many extraordinary women broke through this exclusionary zone - from Sappho and Teresa of Avilla to the Jane Austen, George Sand, George Elliot, the Bronte sisters and Emily Dickinson and, finally, the great women authors of the last century when women achieved access to full professional education and mainstream, speaks for itself. A study of transgenerational trauma between mothers and daughters would make a fascinating complement to the present study. Women have their own singular scars and their traumatic woundings are no less in need of healing than those of fathers and sons. See here, for example, the work of Luce Irigaray, Julia Kristeva and Shelley Rambo, 'Response to Richard Kearney's 'Narrative Catharsis', a paper delivered at the Boston College conference on 'Trauma and Nachträglichkeit', March, 2012. For more details on the writings of Irigaray's feminist reading of the role of mothers and daughters in western culture including her critique of Freud's fort/da scenario as matricidal representation - see Note 4. 
6) See Claude Lévi-Strauss, 'The Structural Study of Myth' and related essays on the therapeutic power of stories, 'The Effectiveness of symbols' and 'Shamanism and psychoanalysis', in Structural Anthropology, Basic Books, 1963. See our commentary on this discussion of the cathartic potential of oral, written and cinematic narratives (in myths, novels and holocaust testimonies) in Richard Kearney 'Narrating Pain: The Power of Catharsis' in Richard Bégin and Lucie Roy, ed. Figures de La violence, Collections Esthétiques, L'Harmattan, Paris, 2012, and parts 1-2 and 4 of On Stories, Routledge, London and New York, 2002, pp 1-76 and 125-156.

7) Speaking of transgenerational trauma in the Odyssey, there is also the trauma of the son - Telemachus. In addition to the childhood wound at his father's premature departure and mother's subsequent obsession (echoes of Hamlet) - there are several accounts of the child Telemachus being subjected to a terrifying death experience. According to Hyginus, Palamedes (a friend of Odysseus) "put the baby Telemachus in front of his father's ploughshare... to expose Odysseus' pretended madness." But there are further allusions to patricide and infanticide in the story, told by Eugammon of Cyrene in the epic Telegoneia, which describes Telemachus being "killed unwittingly by Telegonus, Odysseus' son by Circe". Telemachus' traumatic wounds, like those of his father, remain, however, largely hidden and uncovered - alluded to rather than exposed (see here note 14 below). The father-son cycle of patricide-infanticide clearly finds echoes in the later Oedipus cycle. But this is too complex a maze to go into here. Work for another day, or a much longer 
footnote! I am grateful to my friend and colleague, John Manoussakis, for many of these references.

8) Erich Auerbach, 'The Scar of Odysseus' in Mimesis: The Representation of Reality in Western Literature (A. Francke Verlag, 1946; English translation Princeton University Press, 2003). I am also indebted here to pioneering recent research on the theological and hermeneutic meanings of wounds and scars by Shelley Rambo (see her response to this paper in the 'After the Unspeakable' conference at Boston College, March 2012) and Karmen MacKendrick (Word Made Flesh: Figuring Language at the Surface of Skin, Fordham University Press, New York, 2004). See also our examples of writing the flesh in our discussion of carnal hermeneutics - Queequeg's tattoos, stone and skin hieroglyphics etc - in 'What is Diacritical Hermeneutics?, Journal of Applied Hermeneutics, Vol 1, no 1, University of Calgary, 2011.

9) We might note here, in parenthesis, how the concluding Homeric meal of Ulysses-Telemachus is replicated in the scene where the wounded Stephen and Bloom share a cup of cocoa in Bloom's house in Eccles St - disenchanted biological paternity, with all its inherited scars, opening onto spiritual paternity; hostility giving way to hospitality. If the opening chapter of Ulysses is called 'Telemachus', the last encounter of Bloom with Stephen is fittingly called 'Ithaca'(preceded by 'Eammaus'). But this culminating moment of father-son sharing is not the end of the novel. As Joyce writes in a letter to Valéry Larbaud, 'Ithaque est stérile, Pénélope le dernier cri'. (See our commentary on this subject in 'The Case of Stephen Dedalus' in On Stories, 
pp 17-30 and 'In the Text: Joyce, Proust, Woolf' in Anatheism, Columbia University Press, New York, 2010, pp 103-110). Without the inclusion of Molly - the excommunicated third of the trinity- the communication of Bloom and Stephen remains less full communion than another failed Eucharist, or as Joyce puts it, 'the dry rocks of mathematical catechism'. The father-son dyad is a Logos manqué unless it includes 'the last word' of the woman: le dernier cri of Molly's 'yes'. The Excluded Middle as woman informs the father-son trauma in Joyce's three stories - Hamlet (the exclusion of Ann Hathaway/Gertrude/Ophelia), The Odyssey (the absence of Penelope for most of the narrative), Ulysses (the denial of Stephen's mother on her deathbed and the deferral of Molly's voice to the epilogue). And one might add to these three narratives a fourth - the Bible - especially in view of Stephen Dedalus' extended theological exposition of his Hamlet thesis, namely: any divine Trinity that privileges Father and Son (and a male SpiritLogos) to the exclusion of woman is a failed art. As Joyce's Liffey washerwomen sing - 'mememormee' (Finnegans Wake). In short, the 'mothers of memory' are forgotten by fathers and sons at their peril. And this observation raises, by extension, the question of the difference between intergenerational stories of fathers and sons and alternative stories of mothers and daughters, fathers and daughters and mothers and sons. As mentioned in note $5 \mathrm{a}$ above, the predominance of the father-son category from classic texts like the Odyssey and Aeneid to modern narratives like Fathers and Sons, The Brothers Karamazov, A Long Day's Journey into Night, 
Death of a Salesman and of course Ullysses itself - is no doubt largely due to the patrilineal and predominantly male character of Western literary culture up to the twentieth century. One might also mention here Herman Melville's comment about the all male story Moby Dick: "I wrote a wicked book and remain as spotless as the lamb'. Charles Olsen interprets this in terms of a dramatic catharsis deriving from the choral structure of Greek tragedy which Melville adapts as a narrative working through of father/son wounds (Call me Ishmael, Johns Hopkins UP, Baltimore and London, 1997, p 56 and pp 131-134)

10) On the 'collapse of witnessing' see Dori Laub, 'Truth and Testimony: The Process and the Struggle' in Cathy Caruth (ed), Trauma: Explorations of Memory, pp 61f. In his reading of Hamlet, Lacan reads this collapse or breakage in language as central to the experience of trauma and mourning. 'The work of mourning is first of all performed to satisfy the disorder that is produced by the inadequacy of signifying elements to cope with the hole that has been created in existence, for it is the system of signifiers in their totality which is impeached by the least instance of mourning' ('Desire and the Interpretation of Desire in Hamlet', in Literature and Psychoanalysis ed. Shoshana Felman, The Johns Hopkins University Press, Baltimore and London, 1982 pp 11f. I am grateful to Richard Boothby for bringing this citation to my attention). On this account, we could see Hamlet as Shakespeare's effort to respond to the crisis of being a defaulting father and son (after the death of Hamnet), which provoked a corresponding crisis in 
language which the play itself is an attempt to reinvent - that is by weaving a symbolic web of words to fill in 'the hole', namely, the lack left by the trauma of death. As Hamlet famously quips: 'words, words, words...'

11) For psychoanalytic readings of Hamlet, see for example, André Green, Hamlet et Hamlet: Une interprétation psychanalytique de la représentation, Balland, Paris, 1982. Green notes, among other things, that Hamlet is the most written about figure in western literature after Jesus Christ; Jacques Lacan, 'Desire and the Interpretation of Desire in Hamlet' (op.cit, pp 12-52); Nicolas Abraham, 'The Phantom of Hamlet or the Sixth Act' in Diacritics, vol 18, no 4, 1988, p 188; and John P. Muller, 'Psychosis and Mourning in Lacan's Hamlet' in New Literary History, vol 12, 1980. On the related questions of trauma, history, memory and ghosts, see the extraordinary psychoanalytic readings of Françoise Davoine and Jean-Max Gaudillière, History Beyond Trauma: Whereof one Cannot Speak Thereof one Cannot Stay Silent, trans. Susan Fairfield, Other Press, New York, 2004, especially the section, 'Fighting the Ghosts', pp 184f. A central insight of the authors, in this work and elsewhere, is that trauma speaks to trauma. Most of their examples are drawn from their own clinical cases of analyst and analysand, but the model can be extended to other situations; in our own literary cases above, for instance, we might cite the wounded Bloom speaking to the wounded Stephen, the swineherd and nurse receiving the estranged Odysseus, the traumatized Prince Hamlet speaking to his ghostly father (whom no one else recognizes), and so on. 
12) See Paul Ricoeur, Time and Narrative, vol 1, ch 2, Chicago UP, Chicago, 1984. Catharsis must be understood less as an avoiding of the pathos of pity and fear, by dispensing with them, than as a therapeutic voiding of their pathological function as excessive identification (pathological pity) or excessive recoil (pathological fear). Catharsis thus functional as a purgative rendering which distills these primary human emotions/drives/affects (pathemata) until pity is transformed into compassion and fear into serenity (what Yeats refers to when he writes of 'gaiety transfiguring all that dread'). In this sense, cathartic 'purgation' should be understood as a refining transfiguration rather than as a eliminative evacuation. Catharsis involves a mimetic revisiting of extreme affects in the form of 'imitated and emplotted action' - a muthos/mimesis (Aristotle) which liberates destructive passions into creative powers. This liberating releasement, in turn, offers a special kind of cathartic 'pleasure', mixing together thought, imagination and affect. In the formal structure of Ulysses, for example, imitated 'pity' would be what we feel for the humbling vulnerability of Bloom and Stephen (what Stephen in A Portrait, calls 'identification with the sufferers') and imitated 'fear' would be what we experience as detached witnesses of this action and suffering (what Stephen calls acknowledgment of the 'secret cause') - a detachment provoked and performed by the estrangement devices of Joyce's highly experimental style and language. The particular 'pleasure' of catharsis has nothing to do with voyeurism or Schadenfreude - as we behold traumatic acts of murder, incest, war and rape (see again Aristotle in the Poetics) - but 
with a very singular equipoise between deeply experienced empathy and wise disinterestedness (to borrow from Kant in the Critique of Culture). Too much 'pity' and we fall into sentimentalism and sensationalism; too much 'fear' and we fall into cruel indifference. For a more detailed analysis of the healing potentials of catharsis through pity and fear, see our 'Narrating Pain: The Power of Catharsis', op.cit.

It is important to note that when dealing with catharsis, as Aristotle reminds us, we are not just dealing with the 'writing cure' of the author but the 'reading cure' of the reader. The purgation of pity and fear is, for Aristotle, something primarily experienced by the spectator or recipient of a tragic drama (muthos-mimesis). And here we might add Proust's notion that a cathartic novel is one which invites us to become the readers and writers of our own lives: 'It was my book, and thanks to it, I enable them (the readers) to read what lay within themselves' ( $A$ la Recherche du temps perdu, Gallimard, Paris, Pleiade, vol 111, page 1033).

For a more empirical and cognitive account of the effectiveness of a 'writing cure' see A.D. Peterkin and A.A. Prettyman, 'Finding a Voice: Revisiting the History of Therapeutic Writing', Med Humanities, 35, 2009, pp 80-88. Here the authors cite clinical evidence that 'supports a positive impact of expressive writing in many domains of physical and psychological health, particularly following trauma'(p 80).

13) On 'le traumatisme orginel' see the interesting analyses of Emmanuel Levinas in terms of our common human experience of birth, separation, exposure, 
and death. These are inescapable existential traumas which every human being encounters; and in a sense such traumatic encounter with otherness is a precondition of ethics. On a more phylogenetic or genealogical level, see the notion of 'original trauma' as a deep structure of our ontological or inherited psyche in Giorgio Agamben's theory of language and in Freud's theory of the primal woundings of castration, parricide and infanticide in Totem and Taboo and the primal separation of child and mother (Ernst and Sophie) in Beyond the Pleasure Principle. Nor should it go unnoted that two of the primal scenes of monotheistic religion are the traumatic sacrifice of Isaac by his father Abraham (a trauma of fear and trembling) and the sacrifice of Jesus by and for his Father in heaven (a trauma of crucifixion). René Girard and several contemporary theologians dispute the 'sacrificial' character of these scenarios (and I think them correct); but it remains the case that the fatherson drama, in whatever form, became a dominant story in the western Abrahamic tradition in which the religious imaginations of both Shakespeare and Joyce were steeped. And as the narratives of Homer and Sophocles remind us, it was also deeply inscribed in the Greek narrative imagination (both epic and tragic).

14) On the role of narrative catharsis in holocaust testimonies - and related questions of oral and written testimony - see Helen Bamber, The Good Listener, Wiedenfeld and Nicholson, London, 1998, pp 88f. See also our discussion of the limits of language and imagination when testifying to the Shoah in the work of Primo Levi, Claude Lanzmann and Stephen Spielberg in 
Richard Kearney, On Stories, Routledge, London and New York, 2001, pp 47-

76. For critical discussions of catharsis as a therapeutic response to trauma see Judith Herman, Trauma and Recovery, op.cit; Claude Lanzmann, 'Holocaust: La représentation impossible', Le Monde, February, 1994 and 'The Obscenity of Understanding' in Memory and Trauma, ed Cathy Caruth, op.cit; and also the essays by Dominick La Capra, Berel Lang and Hayden White in Probing the Limits of Representation, ed Saul Friedlander, op.cit. There are also problematic limits to narrative catharsis and recovery in the tragic ethnocidal tramas suffered by certain colonized and deracinated peoples. There are of course cultures where the recovery of trauma through narrative may be seriously threatened. In Radical Hope: Ethics in the Face of Cultural Devastation, Harvard UP, Cambrdige, MA, 2006, Jonathan Lear suggests that in the case of certain extreme cultural catastrophes and ethnocides (his chosen example is that of the indigenous Crowe nation in Montana and Dakota) the problem is not one of competing narratives so much as of being able to retrieve any kind of narrative at all which could make sense of the traumatic calamity of massacre or near extinction. The death is not just of physical bodies but of bodies who may survive but have suffered the death of consciousness of their life world (Husserl's Lebenswelt, MacIntryre's 'narrative form of life'). Such a rupture in continuous shared experience engraves a wound in the unconscious body of the traumatised people such that narrative recovery, working-through and catharsis become deeply problematic. The social group of certain deracinated indigenous 
peoples may survive in name but only as 'partly living' and sometimes repetitively 'acting out' irretrievable and unnamable past pain in forms of displaced violence and self-injury (alcoholism, domestic and sexual abuse, eating disorders, depression, crime). Hence the importance of such 'culturally lobotomised' communities finding some kind of 'voice' in new poets, artists, musicians, dramatists, film makers, storytellers, dream-makers. See the insightful analysis of Luke Gibbons, 'Mourn - and Move Onward' in The Field Day Review, edited Seamus Deane, Newman House, Dublin, 2008.

15) See Nikolas Abraham and Maria Torok, The Shell and the Kernel: Renewals of Psychoanalysis. Trans. Nicholas Rand, University of Chicago Press, Chicago, 1994, Ch V, 'Secrets and Posterity: the Theory of the Transgenerational Trauma' and The Wolf Man's Magic Word: A Cryptonomy, Trans Nick Rand with a Forward by Jacques Derrida, 'Fors: The Anglish Words of Nicolas Abraham and Maria Torok', University of Minnesota Press, 2005.

16) On this question of eviction, famine and banishment in Ulysses, see Luke Gibbons' fascinating study 'Famished Ghosts' in Dublin James Joyce Studies, vol 2, ed Anne Fogarty and Luca Crispi, National University of Ireland, Dublin, 2009, pp 1-12). Gibbons begins his essay by suggesting that Joyce's use of dreams and visions in Ulysses tap into a special kind of ana-chronology which acknowledges a past that is never past but is constantly repeating itself into the present and future. This he claims is the essence of Joyce's references to the special nachträglich temporality of the 'nightmare of history': 'One of the traumatic aspects of the 'nightmare of history' in Ulysses is that the past is not confined to dream but may visit its terrors again on the present. 'Coming events cast their shadow before' (U8: 526): in 
recapitulating what has already happened, dreams may also cast a dark shadow on the future'. Referring to the curious fact that Bloom carries a potato in his pocket throughout the narrative, Gibbons identifies a series of telling associations and affiliations between the themes of exile (Bloom himself is a wandering ex-Hungarian Jew), famine (the Irish famines of the last half of the $19^{\text {th }}$ century), souperism (certain Protestant churches provided soup for 'famished' Irish Catholics on condition they convert) and recurring hunger in Joyce's own Dublin(even members of Stephen Dedalus' family suffer from hunger). Gibbons writes: 'The presentation of spiritual salvation in the guise of food signals one of the abiding themes of 'Lestrygonians': the specters of famine and 'souperism' that followed the linking of food relief with proselytism during the Great Famine. 'Good Lord, that poor child's dress in flitters. Underfed she looks too. Potatoes and marge, marge and potatoes. It's after they feel it' (U8: 41-2). On Bachelor's Walk, Bloom spots one of the destitute Dedalus sisters hovering around Dillon's auction rooms: 'Must be selling some furniture' (U8: 29). When the starving Dedalus sisters, Katey and Boody, re-appear in the 'Wandering Rocks' chapter, they are living off pea soup provided by the Sisters of Charity home in Gardiner Street (223). Bloom's intermittent memories of the Famine and its ghoulish legacy in Ireland, are, as Gibbons shows, touched off, literally, by the potato he carries around with him all day as a talisman of sorts, and which he confirms is in his pocket as he leaves his house for the butchers at the beginning of 'Calypso'. As he approaches Davy Byrne's for a midday 
lunch, Bloom turns to thoughts of religious conversion, food and disease, prompted by memories of the emaciation associated with Soyer's infamous soup kitchen in the Phoenix Park during the Great Famine:

Suppose that communal kitchen years to come perhaps. All trotting down with porringers and tommycans to be filled. Devour contents in the street. . . .. My plate's empty. After you with our incorporated drinkingcup. Like sir Philip Crampton's fountain. Rub off the microbes with your handkerchief. Next chap rubs on a new bunch with his. Father O'Flynn would make hares of them all. Have rows all the same. All for number one. Children fighting for the scrapings of the pot. Want a soup pot as big as the Phoenix Park ... Hate people all around you ... Soup, joint and sweet. Never know whose thoughts you're chewing . . . . Famished ghosts. Ah, I'm hungry (U8: 704-6; 710-15; 718-19; 730) ${ }^{\mathrm{i}}$

The point of ghosts is to remind us that the past may materialize in the present, and that far from being distant memories, chronic hunger, disease and sectarian wars still stalked colonial Ireland". And, one might add, continue their hauntings in more indirect but no less destructive ways in which repressed traumas return and act themselves out obsessively, repetitively, unconsciously in the pathological behaviors of alcoholism, abuse and depression. Gibbons adds this very informative bibliographical note on the role of ghostly (repressed and recurring) famine memory in Joyce: 'Mary Lowe Evans was the first to note the connection with Soyer's soup kitchen at the Phoenix Park, and to bring out the recurrent anxiety over famine in Ulysses. She was also the first to link wider questions of 'souperism' with the mention of the Rev. Thomas Connellan in 'Lestrygonians', as discussed below. See her pioneering and still valuable study, Crimes against Fecundity: Joyce and Population Control (Syracuse: Syracuse University, 1989), esp. pp. 16-29'. For subsequent discussions cited by Gibbons, see Emer Nolan, James Joyce and 
Nationalism (London: Routledge, 1996), pp. 79-119; Julie Ann Ulin, “ “Famished Ghosts": Famine Memory and Bloom's Fantasy of Inclusion in James Joyce's Ulysses.' Bloomsday 100 Symposium, The National College of Ireland, Dublin, June 12-19, 2004; Bonnie Roos, 'The Joyce of Eating: Feast, Famine and the Humble Potato in Ulysses', in George Cusack and Sarah Goss, eds., Hungry Words: Images of Famine in the Irish Canon (Dublin: Irish Academic Press, 2006). Gibbons sees the recurring motif of Bloom's talismanic potato (recalling his own departed mother) and Stephen's repressed memories of his own deceased mother (who returns as a neglected and repudiated ghost from the sea) as basically phantasmal returns of a ghostly forgotten past. 'When Bloom seeks the return of his talismanic potato in 'Circe', it is on the grounds that 'it is nothing, but still, a relic of poor Mamma' (U15: 3513): earlier it transpires that the 'shrivelled potato' (U15: 289) is among her mementoes. Stephen's haunting by his dead mother recalls the cannibalism of the Famine ('Ghoul, Chewer of Corpses' (U1: 278; also U15: 4214)) while her grisly specter insists that his starving sister, Dilly 'make you that boiled rice every night after your brainwork' $(U 15,4201-2)$. The death of Stephen's mother, with 'the ghostcandle to light her agony' (U1: 274) is equated in 'Proteus' with the figure of the undead, the vampire, who emerges from the sea: 'In sleep the wet sign calls her hour, bids her rise. Bridebed, childbed, bed of death, ghostcandled. OMNIS CARO AD TE VENIET. He comes, pale vampire, through storm his eyes, his bat sails bloodying the sea, mouth to her mouth's kiss'. (U3: 396-9). That the recurring past belongs not just to personal memory but to history is clear from indictment of the potato through its association with Sir Walter Raleigh 'who brought from the new world 
that ... killer of pestilence by absorption'(U15: 1356-7), sentiments echoed by the eerie chant of the 'Daughters of Erin' in 'Circe' linking the potato once again with religion: 'Potato, Preservative against Plague and Pestilence, pray for us' (U15: 1952).

17) See Michael D Higgins and Declan Kiberd, 'Culture and Exile: The Global Irish' in New Hibernia Review, , vol 1, no 3, 1997, pp 10-11: Certain critics locate this central pain of banishment at the very heart of Joyce's writing: 'Some of the greatest works of literature have been written by exiles who wished by an act of imagination to define the components of that place from which they had been estranged. It was this 'note of banishment' which Joyce detected in....Shakespeare. Shakespeare's move from Stratford to London was , for Joyce, an action as momentous in its day as his own migration from Dublin to Paris, and so he read the whole canon, and not solely The Tempest, as an ongoing narrative of exile and loss: 'The note of banishment, banishment from the heart, banishment from home, sounds uninterruptedly from The Two Gentlemen of Verona onward till Prospero breaks his staff, buries it certain fathoms in the earth and drowns his book'( Ulysses). Art will always undertake to restore a world lost under the brute evictions of history; music, dance, dreams, literature are what fill the vacuum when an eviction has occurred'. 